\title{
The Positive Principles And The Strategic Advantage Of Higher Education As Part Of The International Collaboration Programs
}

\author{
K Prihartono Aksan Halim, Politeknik Piksi Ganesha, Bandung, Indonesia
}

\begin{abstract}
If the performance improves superior efficiency and the implications for competitive gain are addressed, ethically committed in the higher education service triangle sense can be met. The objective of this study was to investigate agreed ethics and to consider the comparative advantage of higher education in the service marketing triangle. The tool used is a descriptive and succinct survey method. The sample consists of 330 polytechnic students in West Java, calculated by the cluster proportional random sampling process. The research involves 330 students. The Partial Least Square (PLS) multivariate regression test was used for hypothesis testing. The data analysis was performed using both the SmartPLS 2.0 programs and the SPSS for Windows. The results show promising ethics in the sense of the service triangle and competitive advantage. Promising ethics can also be done in the context of the service marketing triangle if the success of higher education strengthens international collaboration, and the dedication to ethics can be optimally applied, and the results can be achieved for the competitive advantage of higher education. The objective is to: (1) improve the quality of education, (2 ) increase study quality, (3) enhance skills and capability of academic staff and researchers, (4) boost graduate ability and competency, (5) enhance the university's reputation for international and financial benefits, (6) meet the demands o Internationalisation of higher education There are five ( 5) general corporate governance principles known as GCG. These are rights, honesty, responsibility, duty, justice.
\end{abstract}

Keywords: Promising ethics, competitive advantage, international collaboration.

Received: $19.11 .2020 \quad$ Accepted: 20.12.2020 $\quad$ Published: 15.01 .2021

\section{INTRODUCTION}

In Indonesia, the state of higher education (PT) faces competition, not only local but regional and global. Globalization has led to competition from non-local or regional educational institutions as well as from foreign institutions. Global competition impacts in the sector of education, one of the four ways in which higher education has been internationalized, namely (1) opening university branches to other countries ( e.g., expansion of the class), for example, to American universities to open an Asian branch; (2) collaboration among the national universities; Indonesian universities would eventually face public and private global competition.

The competition will be heavier and stronger between private universities. There are currently about 3147 schools with 15,819 courses in Indonesia. The West Java is home to $15.6 \%$ or 491 schools. The number of colleges in West Java in Indonesia is the biggest. In 2010, almost 40 percent of these schools had been found unhealthy due to student shortages at 115 private colleges (PTS), located in West Java (Area IV Kopertis 2011).

Polytechnics' competitive advantage needs to be adapted to the capability and diversity of its capital to achieve a greater value, which is deemed to be worth the confidence of polytechnics. The technical training programs, in accordance with the respective fields, benefit, performance, product characteristics, product utilization of the activities, classification of the products and product categories of the competitor, were considered to enhance their expertise and functional abilities. Thus, in consideration of the empirical evidence of the general ethic of marketing theory and the ethical phenomenon, the competitive advantage in international collaboration programs will form part of the need to consider the role of ethics in the context of the services triangle in higher education.

\section{RESEARCH METHODOLOGY}

The best theory used in this analysis is the theory of consumer behavior. In order to comply with their specifications, Schiffman and Kanuk (2000) argue that customers are privately owned to discover, buy, use, 
compare, and sell products. The center of customer behavior is two variables: (1) (decision) and (2) action and physical activity, including everyone in the assessment, purchase, and use of goods and services.

The medium-range theory or theory used in this analysis is strategic marketing of educational services with the combination theory of services, competitive advantage theory, and marketing theory. According to Fox, educational firms have several marketing problems for educational institutions in the area of strategic strategies, ranging in a drop in students registering, restricted training grants, and other sources of revenue, while operating costs continue to rise. It is also worth noting that educational institutions rely on their market dependence. Many schools face shifts in demands and needs as new students and sources of funding become more competitive.

(1) Iversen (2002) indicates that the continued creation and building of synergies between the business's assets and facilities is a way to achieve a competitive advantage because the use of the assets allows assets to use and expand the products efficiently since the company has different goods with similar assets.

Obligations are a simple responsibility, unlike the ethical commitments made by anyone who receives promises. This moral obligation creates a duty to honor other people's obligations. Berry stressed that the obligations of the client were the foundation on which the relationship between providers could be established. This has implications for the three activities: making ambitious commitments, meeting, and maintaining responsibilities when the service is delivered, in order to enable the services system to fulfill its promises (Bitner, 1995). The three primary marketing strategies are external marketing, digital marketing, and internal marketing. The concept demonstrates a group of connections that work together to create, promote, and distribute services known as the main players.

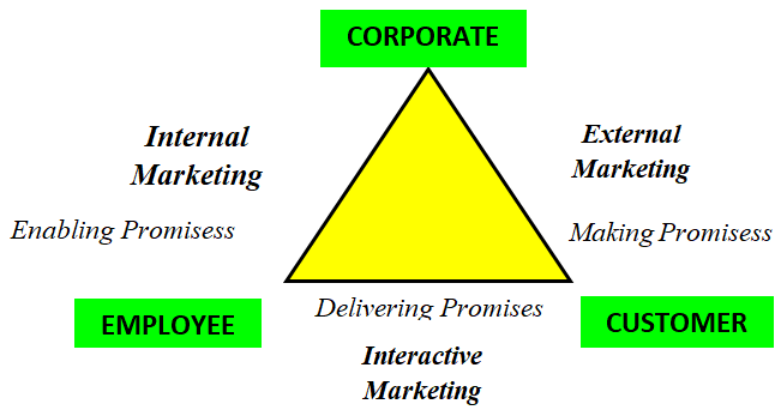

Figure 1. Service Triangle

Source: Valerie A. Zeithaml dan Mary Jo Bitner. 2000. p 16 (adapted)

Binter (1995) concludes that the operation of the organization to attempt to deliver on promises has much to do with capacity, potential, motivation, and the framework and that the company's activities contribute to the fulfillment of promises, and that AMA(2004) concludes that provider ethics are committed to delivering on their commitments and obligation effects The most important ethical considerations to make the most guarantees possible are necessity and accountability for the student community. The compiled framework for analysis is

\begin{tabular}{|l|l|l|}
\hline $\begin{array}{l}\text { Promises Ethics = PE } \\
\text { In service marketing } \\
\text { triangle context }\end{array}$ & $\begin{array}{l}\text { Competitive Advantage = CA } \\
\text { 1) Making promises ethics } \\
\text { 2) Enabling promises ethics } \\
\text { 3) Delivering promises } \\
\text { ethics }\end{array}$ & 1) Service Unique \\
& 2) Benefit \\
\end{tabular}

Figure 2. Compiled Research Paradigm 
International relations (IR) or international affairs are either political science or interdisciplinary academic areas, depending on the academic institution, similar to global studies, where students take a range of international programs with an emphasis on social sciences and humanities. International diplomacy is an analytical area and a sector for public policy, which should also be constructive, which legislative since they evaluate and formulate a specific State's foreign policy.

Table 1. From Cooperation Coordination to Collaboration

\begin{tabular}{|c|c|c|}
\hline $\begin{array}{l}\text { Cooperation } \\
\text { 1. Short term } \\
\text { 2. Informal Relations } \\
\text { 3. No clearly defined mission } \\
\text { 4. No defined structure } \\
\text { 5. No planning effort } \\
\text { 6. Partners share } \\
\text { information about the } \\
\text { project at hand retain } \\
\text { 7. Individuals } \\
\text { authority } \\
\text { 8. Resources are maintained } \\
\text { separately } \\
\text { 9. No-Risk } \\
\text { 10.Lower intensity } \\
\text { ***************************** } \\
\text { **** } \\
\text { Informal, no priorities shall } \\
\text { be mutually identified, no } \\
\text { joint planning, details shall } \\
\text { be shared if appropriate. }\end{array}$ & $\begin{array}{l}\text { Coordination } \\
\text { 1. Longer-term } \\
\text { 2. More formal relationships } \\
\text { 3. Understand the mission } \\
\text { 4. Focus on a specific effort or } \\
\text { program } \\
\text { 5. Some Planning } \\
\text { 6. Open communication channels } \\
\text { 7. Authority still retained by } \\
\text { individuals } \\
\text { 8. Resources and rewards are } \\
\text { shared } \\
\text { 9. Power can be an issue } \\
\text { 10.Some intensity } \\
\text { ********************************** } \\
\text { A more close working } \\
\text { relationship an is } \\
\text { established, and some } \\
\text { planning and } \\
\text { coordination } \\
\text { required. Therefore. }\end{array}$ & 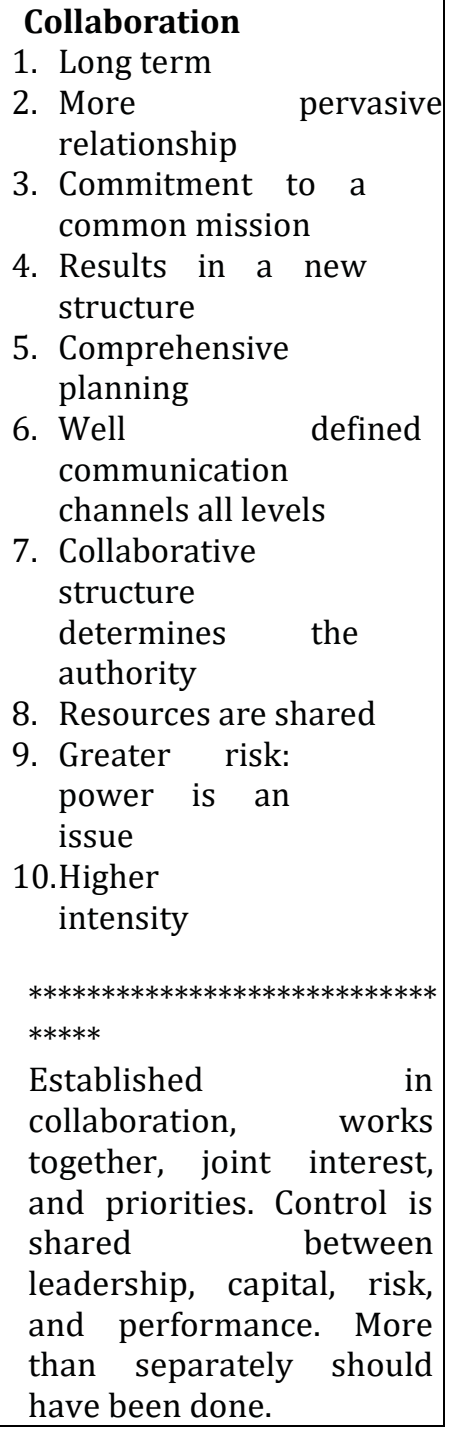 \\
\hline
\end{tabular}

Adapted from the brochure AASL "Collaboration"

In 1994, Collaboration Handbook: Production, Sustainment, and Enjoyment of The

The day was produced based on research by Winer \& Ray.

\section{Operationalization And Measurement}

This study is descriptive and validated by polytechnic students in West Java in 2014. The students of the Polytechnic were the unit of research in this study. A period of time (time horizon) was used in this analysis, and a shoot of the cross-section data form was used. In the descriptive test, the mean weighted value / WMS was used. A method of Structural Equation Modeling (SEM) based on a variety of variables that is the Partial 
Least Square (PLS) was used as an analysis tool in the verification studies of modeling and solution techniques.

Table 2. Operationalization and Variable Measurement

\begin{tabular}{|c|c|c|c|c|}
\hline \multirow{2}{*}{$\begin{array}{l}\text { Latent } \\
\text { Variable \& the } \\
\text { concept }\end{array}$} & \multicolumn{3}{|l|}{ Manifest Variable } & \multirow[t]{2}{*}{ Scale } \\
\hline & Dimension & Indicator & Measurement & \\
\hline \multirow{2}{*}{$\begin{array}{l}\text { Promises Ethics } \\
\text { In Service } \\
\text { Marketing } \\
\text { Triangle } \\
\text { Institutes' } \\
\text { dedication to } \\
\text { promises } \\
\text { (honesty, } \\
\text { integrity, } \\
\text { transparency, } \\
\text { and also clarity) } \\
\text { to what the } \\
\text { promises } \\
\text { (system) allow } \\
\text { and how they } \\
\text { deliver, as well } \\
\text { as to keep their } \\
\text { promise under } \\
\text { the ethical code } \\
\text { decided on in } \\
\text { the Service } \\
\text { Marketing } \\
\text { Triangle's } \\
\text { approach. }\end{array}$} & \multirow{2}{*}{$\begin{array}{l}\text { External } \\
\text { marketing efforts, } \\
\text { where a company } \\
\text { makes promises } \\
\text { clearly and } \\
\text { honestly to the } \\
\text { consumers about } \\
\text { what companies } \\
\text { (Polytechnic) can } \\
\text { provide to the } \\
\text { consumers. }\end{array}$} & 1. Honesty & $\begin{array}{l}\text { a) Conditions of the physical } \\
\text { lecture building } \\
\text { b) Conditions of educational } \\
\text { support facilities } \\
\text { c) Conditions of classroom } \\
\text { lectures } \\
\text { d) Conditions of the library } \\
\text { e) Condition of teaching and } \\
\text { learning tools } \\
\text { f) Learning Method Description }\end{array}$ & \multirow[t]{2}{*}{$\begin{array}{l}\mathrm{O} \\
\mathrm{R} \\
\mathrm{D} \\
\mathrm{I} \\
\mathrm{N} \\
\mathrm{A} \\
\mathrm{L}\end{array}$} \\
\hline & & 2. Clarity & 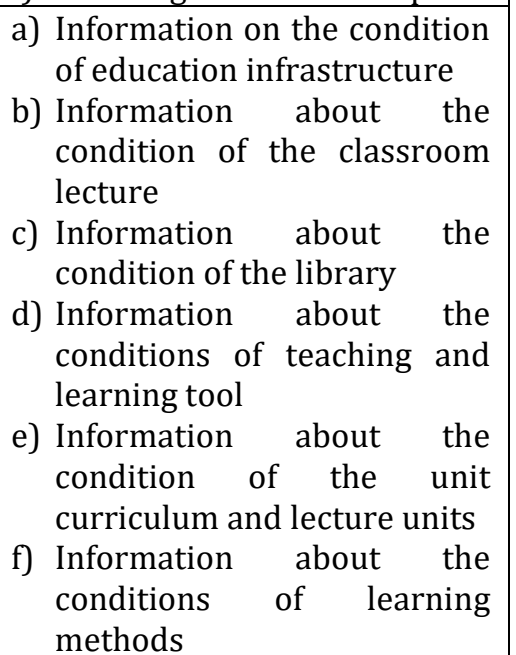 & \\
\hline & \multirow[t]{2}{*}{$\begin{array}{l}\text { 2) Enabling } \\
\text { Promises: } \\
\text { the activity of the } \\
\text { company to try to } \\
\text { keep the promise } \\
\text { that had been } \\
\text { given to } \\
\text { consumers with } \\
\text { the ability, skills, } \\
\text { tools, and } \\
\text { motivation and } \\
\text { also the } \\
\text { availability of the } \\
\text { system to deliver. }\end{array}$} & $\begin{array}{l}\text { 1. Commitme } \\
\mathrm{nt}\end{array}$ & $\begin{array}{l}\text { a) The seriousness of the } \\
\text { institutions in providing } \\
\text { campus } \\
\text { b) The seriousness of the } \\
\text { institutions in providing } \\
\text { college building facilities } \\
\text { c) The seriousness of } \\
\text { institutions in providing } \\
\text { learning space } \\
\text { d) The seriousness of the } \\
\text { institutions in dealing with } \\
\text { academic problems } \\
\text { e) The responsibility for an } \\
\text { education institution } \\
\text { f) Responsibility of institutions } \\
\text { to improve the quality of } \\
\text { learning } \\
\text { g) The seriousness of the } \\
\text { educational institutions in } \\
\text { accordance with the plans }\end{array}$ & \multirow[t]{2}{*}{$\begin{array}{l}\text { O } \\
R \\
D \\
\text { I }\end{array}$} \\
\hline & & 2. The System & a) The efforts of the institution & \\
\hline
\end{tabular}




\begin{tabular}{|c|c|c|c|c|}
\hline \multirow{5}{*}{$\begin{array}{l}\text { Latent } \\
\text { Variable \& the } \\
\text { concept }\end{array}$} & \multicolumn{3}{|l|}{ Manifest Variable } & \multirow[t]{3}{*}{ Scale } \\
\hline & Dimension & Indicator & Measurement & \\
\hline & & $\begin{array}{l}\text { of Service } \\
\text { Recovery }\end{array}$ & $\begin{array}{l}\text { to restore the service failures } \\
\text { in the use of facilities } \\
\text { b) The efforts of the institution } \\
\text { to restore the service failure } \\
\text { in the library } \\
\text { c) The efforts of the institution } \\
\text { to restore the institution } \\
\text { service failures in the use of } \\
\text { learning spaces } \\
\text { d) The efforts of the institution } \\
\text { to restore the institution } \\
\text { service failures in academic } \\
\text { service } \\
\text { e) The efforts of the institution } \\
\text { to restore the institution } \\
\text { service failures } \\
\text { educational administration }\end{array}$ & \\
\hline & \multirow[t]{2}{*}{$\begin{array}{l}\text { 3) Delivering the } \\
\text { Promise: } \\
\text { namely: activity of } \\
\text { the company to } \\
\text { fulfill what had } \\
\text { been promised in } \\
\text { the form of } \\
\text { service encounter } \\
\text { (Groonroos, 2005; } \\
\text { Kotler and Keller, } \\
\text { 2009) }\end{array}$} & $\begin{array}{l}\text { 1. Service } \\
\text { Customer }\end{array}$ & $\begin{array}{l}\text { a) The physical eligibility } \\
\text { condition of the building } \\
\text { b) The Conformity of the } \\
\text { lecturer's educational } \\
\text { background with the faculty } \\
\text { courses Amnestied } \\
\text { c) The Conformity of the } \\
\text { lecture's material with the } \\
\text { job requirement } \\
\text { d) The Conformity of lecture } \\
\text { material with graduates and } \\
\text { career development } \\
\text { prospects lecture } \\
\text { e) The Conformity of lecturith } \\
\text { material with the adaptation } \\
\text { of the social environment } \\
\text { (e.g., Family \& Society) } \\
\text { f) Lectures administrative } \\
\text { services (such as lecture } \\
\text { schedule, grades, payments, } \\
\text { exam schedules, and } \\
\text { supervising schedule) }\end{array}$ & \multirow[t]{2}{*}{$\begin{array}{l}\text { O } \\
\mathrm{R} \\
\mathrm{D} \\
\mathrm{I} \\
\mathrm{N} \\
\mathrm{A} \\
\mathrm{L}\end{array}$} \\
\hline & & $\begin{array}{l}\text { 2. The } \\
\text { Implementa } \\
\text { tion of the } \\
\text { Personal } \\
\text { Ethics Code }\end{array}$ & $\begin{array}{l}\text { a) The willingness of the } \\
\text { lecturers to give students } \\
\text { the opportunity to ask, } \\
\text { discuss and express an } \\
\text { opinion } \\
\text { b) The objective attitude of the } \\
\text { lecturer in treating students } \\
\text { c) The lecturer's speaking } \\
\text { attitude } \\
\text { d) The attitude of the lecturers } \\
\text { in addressing the academic } \\
\text { issues } \\
\text { e) The attitude of the lecturers }\end{array}$ & \\
\hline
\end{tabular}




\begin{tabular}{|c|c|c|c|c|}
\hline \multirow{5}{*}{$\begin{array}{l}\text { Latent } \\
\text { Variable \& the } \\
\text { concept }\end{array}$} & \multicolumn{3}{|l|}{ Manifest Variable } & \multirow[t]{2}{*}{ Scale } \\
\hline & Dimension & Indicator & Measurement & \\
\hline & & & $\begin{array}{l}\text { in addressing the issue of } \\
\text { personal interests } \\
\text { f) Lecturers efforts in } \\
\text { motivating students }\end{array}$ & \\
\hline & & $\begin{array}{l}\text { 3. The } \\
\text { implementa } \\
\text { tion of the } \\
\text { ethics on } \\
\text { the Ethics } \\
\text { Code } \\
\text { Program }\end{array}$ & $\begin{array}{l}\text { a) Institutional respect on the } \\
\text { student's rights in obtaining } \\
\text { the learning process } \\
\text { b) Institutional justice in } \\
\text { viewing the social status } \\
\text { c) The attitudes of the } \\
\text { institutions in maintaining } \\
\text { the confidentiality of the } \\
\text { student } \\
\text { d) The openness of the } \\
\text { institution in providing the } \\
\text { learning process }\end{array}$ & \\
\hline & & $\begin{array}{l}\text { 4. The } \\
\text { implementa } \\
\text { tion of the } \\
\text { Code of } \\
\text { Ethics in } \\
\text { Customer } \\
\text { Service } \\
\end{array}$ & $\begin{array}{l}\text { a) The politeness of the } \\
\text { customer service staff } \\
\text { b) The efforts of the staff to } \\
\text { maintain the confidentiality } \\
\text { of student academic } \\
\text { information }\end{array}$ & \\
\hline $\begin{array}{l}\text { Competitive } \\
\text { Advantage } \\
\text { The existence of } \\
\text { superiority of } \\
\text { an organization } \\
\text { or a company } \\
\text { (Polytechnic) } \\
\text { that } \\
\text { distinguishes } \\
\text { one } \\
\text { organization/co } \\
\text { mpany from the } \\
\text { other } \\
\text { organizations/c }\end{array}$ & 1) Service Unique & $\begin{array}{l}\text { 1. The variety } \\
\text { of } \\
\text { educationa } \\
\text { 1 services } \\
\text { products } \\
\text { offered } \\
\text { 2. Fee } \\
\text { Waivers } \\
\text { 3. Access to } \\
\text { Service } \\
\text { 4. Convenien } \\
\text { ce } \\
\text { 5. Experience }\end{array}$ & $\begin{array}{l}\text { a) The uniqueness of the } \\
\text { educational service product } \\
\text { variations offered by the } \\
\text { institution } \\
\text { b) Payment of fees (e.g., can be } \\
\text { paid on credit, if it is paid } \\
\text { before the time, there will be } \\
\text { waivers granted) } \\
\text { c) The easiness for the students } \\
\text { to access services products } \\
\text { offered } \\
\text { d) Students comfort in receiving } \\
\text { services } \\
\text { e) Student experiences in } \\
\text { receiving care }\end{array}$ & $\begin{array}{l}\mathrm{O} \\
\mathrm{R} \\
\mathrm{D} \\
\mathrm{I} \\
\mathrm{N} \\
\mathrm{A} \\
\mathrm{L}\end{array}$ \\
\hline $\begin{array}{l}\text { ompany as the } \\
\text { competitors. }\end{array}$ & 2) Benefit & $\begin{array}{ll}\text { 1. } & \text { Facility } \\
\text { 2. Service } \\
\text { 3. Personel } \\
\text { 4. } \text { Prestige }\end{array}$ & $\begin{array}{l}\text { a) Learning facilities and a fully } \\
\text { equipped lab equipment } \\
\text { b) Good service administration } \\
\text { c) The ability of a good lecturer } \\
\text { d) The pride of being in } \\
\text { polytechnic students }\end{array}$ & \\
\hline
\end{tabular}




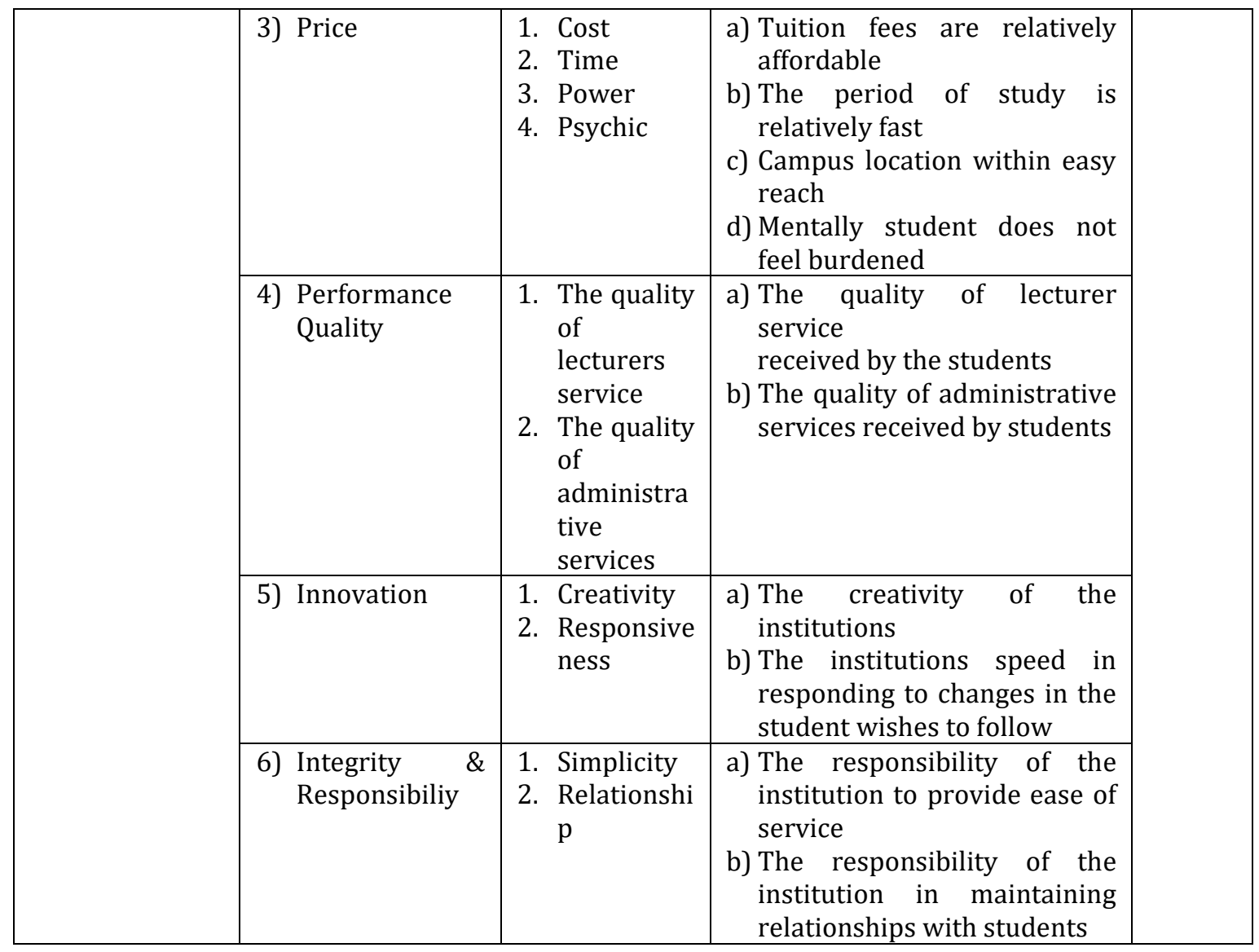

The research population is the general characteristics of the study variables viewed by Polytechnic students. The research unit includes 31 Polytechnics, and the observation unit consists of participating students in West Java at the Polytechnic in private practice. The sample size has been calculated by the number of specimens required for the structural equation model (Structural Equation Model / SEM) of the variant or component-based component (PLS). The sampling method used for all students of a private polytechnic as a population unit is the proportional random sampling method used for the simple cluster (Cochran 2010). The sample size in this analysis is 385 from the results of these measurements.

In 4 stages, the data obtained from the distribution of the questionnaire and from the secondary set of data were coded, processed, processed, and analyzed. The data from the distribution of the questionnaire used to calculate the investigation variables were derived from the responses that were measured at an ordinary level. In order to define the answer to the question as decided by any variable evaluated, a weighted medium scoring was used for descriptive analyses. The following formula provided weighted mean values:

WMS $=\frac{\text { IAS }}{\text { IIS }} \times 100 \%$

where

WMS = Weighted Mean Score, which is the average of value-weighted results, obtained from the ratio of the total actual score with the total ideal score.

$\Sigma$ AS = Actual Score, which is the total score obtained from multiplying the number of respondents, the number of questions, and the scores achieved by respondents.

$\Sigma$ IS = Ideal Score, which is the score obtained from multiplying the number of respondents, the number of questions, and the maximum score for each question.

The results of the Weighted Mean Score, and then it is interpreted by the established criteria, namely: 
Table 3. The Interpretation of WMS (Weighted Mean Score)

\begin{tabular}{|l|l|}
\hline WMS \% & \multicolumn{1}{|c|}{ The Interpretation of WMS } \\
\hline $80.99-100.00$ & Very Good \\
$60.99-80.00$ & Good \\
$40.99-60.00$ & Good Enough \\
$20.99-40.00$ & Not Good \\
$0.00-20.00$ & Bad \\
\hline
\end{tabular}

\section{Research Results}

Regarding to the right of refusal (the right not to respond on statements) of the respondents, then there should be 385 questionnaires collected, the fact is only 330 copies collected, so the number of questionnaires that can be processed is only 330 copies. Here are responses/ perceptions of the respondents on Promises Ethics in service marketing triangle context and Competitive Advantage.

Table 4. Recapitulation of Promises Ethics in service marketing triangle context

\begin{tabular}{|cl|l|l|l|}
\hline Dimention & & Actual Score & Ideal Score & WMS (\%) \\
\hline 1$)$ & Making Promises Ethics & 12,150 & 18,000 & 67.5 \\
\hline 2$)$ & Delivering Promises Ethics & 12,000 & 18,000 & 66.7 \\
\hline 3) & Enabling Promises Ethics & 18,410 & 27,000 & 68.19 \\
\hline Total & & $\mathbf{4 2 , 5 6 0}$ & $\mathbf{6 3 , 0 0 0}$ & $\mathbf{6 7 . 4 5}$ \\
\hline
\end{tabular}

Table 5. Recapitulation of Competitive Advantage Dimension

\begin{tabular}{|rl|l|l|l|}
\hline Dimention & Actual Score & Ideal Score & WMS (\%) \\
\hline 1) & Service Unique & 5,004 & 7,500 & 66.72 \\
\hline 2) & Benefit & 4,190 & 6,000 & 69.83 \\
\hline 3) & Scarifies & 3,900 & 6,000 & 65.00 \\
\hline 4$)$ & Quality Performance & 1,880 & 3,000 & 62.67 \\
\hline 5) & Innovation & 1,880 & 3,000 & 62.67 \\
\hline 6) & Integrity and Responsibility & 2,054 & 3,000 & 68.47 \\
\hline Total & $\mathbf{1 0 , 1 2 2}$ & $\mathbf{1 5 , 0 0 0}$ & $\mathbf{6 5 . 8 9}$ \\
\hline
\end{tabular}

Description:

PE1 $=$ Making promises Ethics

PE2 $=$ Delivering promises Ethics

PE3 = Enabling promises Ethics

CA1 $=$ Service Unique

$\mathrm{CA} 2=$ Benefit

$\mathrm{CA} 3=$ Price

CA4 = Quality performance

CA5 = Innovation

CA6 = Integrity and Responsibility

The Influence of Promises Ethics in Service Marketing Triangle Context on Competitive Advantage

The fourth influence of promises ethics in the service marketing triangle context on competitive advantage, is shown: 


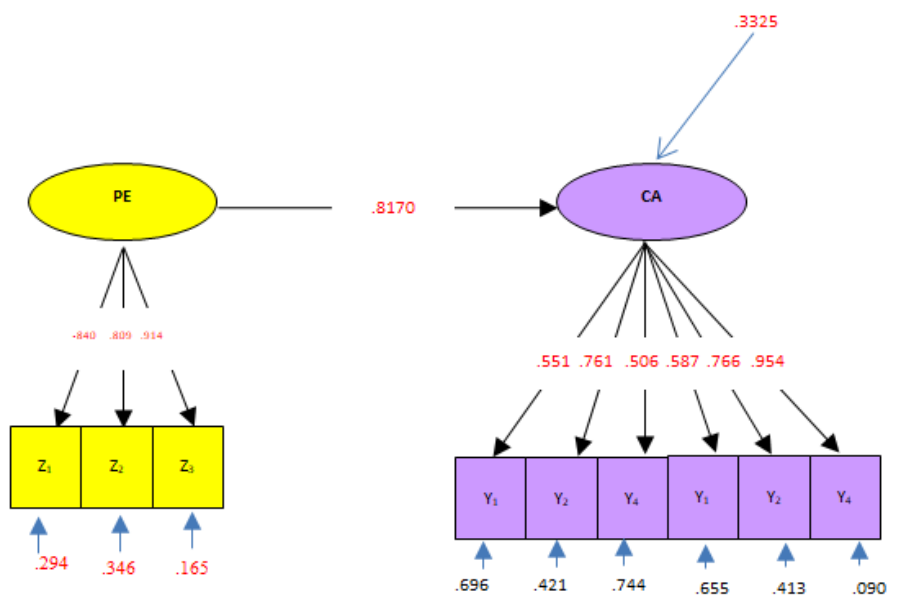

Figure 3. Line Diagram of the Influence of Promises Ethics on Competitive Advantage

The results of statistical calculations using the SmartPLS 2.0 program, shows the influence of competitive advantage on the promises ethic in the service marketing triangle context, in detail, it can be seen as below;

Table 6.Test Result of the Influence of Promises Ethics on Competitive Advantage

\begin{tabular}{|l|l|l|l|l|}
\hline Variable & $\begin{array}{l}\text { Coefficient of } \\
\text { Influence }\end{array}$ & $\mathbf{T}_{\text {observed }}$ & $\boldsymbol{\alpha}$ & Conclusion \\
\hline Promises Ethics (PE) & 0.6675 & 25.673 & 0.05 & Significant \\
\hline Direct Influence & \multicolumn{2}{|l|}{ Indirect Influence } & Total Influence \\
\hline 0.6675 & 0 & 0.6675 \\
\hline
\end{tabular}

According to the researcher, the positive value reflects that promises ethics actually has a positive and significant influence on competitive advantage. To improve promises ethics as a part of a competitive advantage in higher education, it should make collaboration both national and international as well. In Indonesia, since 1999, the National Committee on Corporate Governance (KNKCG) has issued guidance Good Corporate Governance (GCG) first and perfected in 2001. The principle of good corporate governance, namely: Transparency, independence, accountability, responsibility, equality, and fairness.

a) Transparency: the fundamental principle: businesses must have accurate and appropriate information readily accessible and understood by stakeholders in order to preserve their business objectivity.

b) Accountability: The fundamental principle: the organization should be accountable for its results in openness and justice (including colleges).

c) Accountability: the fundamental principle: the corporation (including colleges) must comply with the law and fulfill its social and environmental obligations which can be sustained as part of long-term business sustainability and acknowledgment as good corporate citizens.

d) Independence: The fundamental principle: the organization must be conducted autonomously so that not each other's organ does not govern, and other parties can not intervene.

e) Fairness: the fundamental principle: the company must always consider the interests of shareholders and other stakeholders based on equality and justice standards in carrying out its operations.

Incorporation into college culture can be seen as a means to improve a strategic advantage for the benefit of good corporate governance in higher education. The purpose of the policy of good corporate governance in higher education is that parties play a role in running the college management to understand and perform the functions and role of appropriate authority and responsibility. Parties whose role includes the Board of Trustees, the Board of Trustees, Senate, Rector and the Vice Rector, the Committee (if any), Bureau Chief, Dean and the Vice Dean, The Structural Officials, Faculty, Head of Unit and Employees. 


\section{CONCLUSIONS AND IMPLICATIONS}

Based on the explanation above, it can be concluded as follows ; Promises ethics in the context of service marketing service directly influence the competitive advantage $(66.75 \%)$. And to make more quality in organizing higher education, it should do any programs both nationally and internationally as well. The sociocultural benefits, collaboration could be used to support the development efforts and the development of social and cultural values of the nation in the response to any form of threats, challenges, barriers, international interference, within the framework of the implementation of national development and also collaboration can be used to increase the role and image of the country in international forums and the relationship between the state and the confidence of the international community. To make collaboration, partnership and consortium also very important one to keep Promising Ethics in activities also can be used in higher education. Those are are external marketing, interactive marketing, and internal marketing. The concept shows a linkage group that work together to develop, promote and deliver services that are referred to as key actors.

\section{REFERENCES}

Aaker, David A, V. Kumar, George S. Day, and Rovert P. Leone, 2011. Marketing Research. $10^{\text {th }}$ Edition. USA: John Wiley.

Barney, Jay B and Deleyn N. Clark. 2007. Resource-Based Theory: Creating and Sustaining Competitive Advantage. New York: Oxford University Press.

Carothers, G.H. Jr, Adams, M. in Stahl, M.J. Bounds, G.M (Eds) 2008. Competitive advantage through customer value: the role of value based strategies,

Cravens, David W. and Nigel F. Pierey. 2009 Strategic Marketing. $9^{\text {th }}$ Edition. New York: McGraw-Hill.

Frisque, D. A., Lin, H., \& Kolb, J. A. (2004). Preparing professionals to face ethical challenges in today's workplace: Review of the literature, implications for PI, and a proposed research agenda. Performance Improvement Quarterly, 17(2), 28-45.

Hunter Hall Investment Management Limited (2012). Ethical Investment Policy. Available at http://www.hunterhall.com.au/about.html\#ethical_policy

Kotler, Philip dan Keller. 2009. Marketing Management, $13^{\text {rd }}$ edition. New Jersey: Prentice Hall.

Marta, J-, Singhapakdi, A., Kraft. K. 2008. Personal Characteristics Underlying Ethical Decision in Marketing Situation; A Survey of Small Business Manager. Journal of Small Business Management. 46, pp 589606.

Muchina, S. Popovici, V. 2008. Ethics in Marketing Communication. University of Constanta. Not Published.

Nauman, E. 2005. Creating Customer Value. The Path to Sustainable Competitive Advantage, Thomson Executive Press. Cincinnati, $\mathrm{OH}$.

Nicholls, J, Harris, J., Morgan, E., Clarke K dan Sims, D. 2005. Marketing Higher Education: the MBA experience, The International Journal of Educational Management, Vol. 9, No. 2, pp 59-72.

Olorunniwo, F. Hsu MK dan Udo GF. 2006. Service quality, customer satisfaction and behavioral intentions in the service factory. Journal of Service Marketing. Vol. 20 No. 1, pp 59-72.

Paul, Peter and Jerry Olson, 2008. Consumer Behavior and Marketing Strategy, $8^{\text {th }}$. McGraw Hill.

Petersen, L., Krings, F. 2009. Are Ethical Codes of Conduct Toothless Tigers for Dealing with Employment Discrimination. Journal of Business Ethics. 85:p 501-514

Porter, Michael E., 1999., Competitive Advantage, New York, The Free Press.

Tryon, E., Stoecker, R.M. Martin, A., Seblonka, K., Hilgendorf, A., \& Nellis, M. (2008). The challenge of shortterm service-learning, Michigan Journal of Community Service Learning Spring 2008, p.16-26.

Velasquez, M. 2005. Business Ethic, Concept and Cases. Englewood Cliff: Prentice Hall

Weston, R., Brooks, R., Gladman, J., Senior, K. and Denley, L. (2009). Ethical research in partnership with an Indigenous community. Australasian Psychiatry, 17: Supplement 1, pp. S51-53.

Winchester-Seeto, T. \& Mackaway, J. (2011). Ethics and ethical practice in Learning through Participation (LTP). Discussion paper, Macquarie University.

Zeithaml, Valarie A. and Mary Jo. Bitner. 2003. Service Marketing. New York: Mc Graw-Hill. 